\title{
Shrub Transplanting for Range Improvement
}

\section{in Iran}

\section{NASSER NEMATI}

Highlight: Of three saltbushes tested under the harsh environment of the Central Plateau of Iran, fourwing saltbush (Atriplex canescens) was the most adapted. Transplanting in October and November when transplants were about 20 to $30 \mathrm{~cm}$ high was the most promising practice. Although the cost of transplanting when compared with other revegetation practices is high, the chances of success are also high, and production per hectare can be increased at least three-fold within a 4-year period.

In the United States and Australia, saltbushes (Atriplex spp.) are important sources of winter forage for livestock and wildlife. Through the years various species of saltbushes have been seeded numerous times by ranchers and public agencies. It has been amply demonstrated that establishment of shrubby species by direct seeding is full of uncertainties. This is specially true in arid and semiarid zones of Iran because, when soil moisture is likely to be adequate, temperatures often are either too high or too low, and when temperatures are near optimum soil moisture is often deficient. Research results indicate that transplanting of saltbushes is more satisfactory than reseeding in harsh environments (Plummer et al. 1966).

Studies of native stands in the United States have indicated that fourwing saltbush (Atriplex canescens) grows under a wide range of environmental conditions, withstands drought, heat, cold, and provides palatable, nutritious forage throughout the year. More than 40 years ago the importance of fourwing saltbush was recognized, but attempts to establish the plant were frequently unsuccessful. The main problem in reseeding of this species is slow germination. Much needs to be learned about factors that influence germination (Springfield 1972).

Recently, fourwing saltbush has been used in watershed restoration work on alluvial flood plains of the Rio Puerco drainage in New Mexico. It also is being used to trap sediment above flood detention structures, thereby prolonging the useful life of the structure. Establishment of plant cover behind these structures will also enhance wildlife values (Aldon 1972).

Since reseeding in lower elevations of the Central Plateau of Iran is almost impossible due mainly to unfavorable climatic and edaphic factors, shrub transplanting has been considered the most promising method of revegetation. Three introduced saltbushes, Atriplex canescens, Atriplex lentiformis, and Atriplex halimus, have been successfully established in some areas by transplanting. The study reported in this paper was con-

\footnotetext{
The author is Deputy Director General of Range Management Department of Iran. Manuscript received July 28, 1976.
}

ducted to obtain some information about methods of producing planting stock of Atriplex canescens, Atriplex lentiformis, and Atriplex halimus and methods of transplanting nursery grown plants to the field, comparative cost, relationship of transplant height to percent survival, and productivity analysis.

\section{Study Areas}

Studies were made on three sites in the steppic zone of the Central Province of Iran. Descriptive data for the three sites are presented in Table 1.

During the spring growing season, much of the precipitation falls as light showers that are not effective for plant growth or as high intensity storms from which the moisture is lost by run-off from the poorly vegetated slopes. High winds of several days duration are common. Temperature changes are frequently sudden. In the winter and spring, several warm days may induce germination and growth may be followed by freezing temperatures that kill the seedlings. These characteristics make spring growing period of perennial species extremely difficult.

In general, soils are calcareous and gypsiferus very fine sandy clays, loams, or clay loams. Most soils are extremely low in organic matter and have poor structure. Development of a vesicular surface layer is common to most soils.

Textural and chemical analyses were made using samples from three locations within the Yazdan Range, because this area was considered to be representative of the three areas studied (Table 2). Data presented represent an average for all depths $(5,10,15,20,25$, and $30 \mathrm{~cm})$ at each location. The data illustrate the heterogeneity that exists within a relatively small area. Samples 1 and 2 characterize soil found throughout most of the area. Sample 3 is from a saline clay soil common in this zone.

Wherever human influence is minimal, natural vegetation is composed of strongly rooted perennial grasses, semishrubs, and shrubs. Perennial and annual legumes and a large number of perennial and annual species of other families are present. This vegetation provided abundant valuable forage.

Over-exploitation has resulted in the disappearance of most of the perennial forage species over vast tracts of land. The remaining vegetation thus consists of species with low forage value and those which could best survive due to their particular life forms.

Table 1. Characteristics of the three study areas.

\begin{tabular}{lcccc} 
Name & $\begin{array}{c}\text { Location from } \\
\text { Tehran }(\mathrm{km})\end{array}$ & $\begin{array}{c}\text { Area treated } \\
(\mathrm{ha})\end{array}$ & $\begin{array}{c}\text { Elevation } \\
(\mathrm{m})\end{array}$ & $\begin{array}{c}\text { Annual ppt. } \\
(\mathrm{mm})\end{array}$ \\
\hline Zarand-Saveh Range & $\begin{array}{c}\text { 45 west } \\
\text { Yazdan Range }\end{array}$ & 1000 & 1320 & 205 \\
Karizak Range & 100 south & 1000 & 1070 & 170 \\
\hline
\end{tabular}




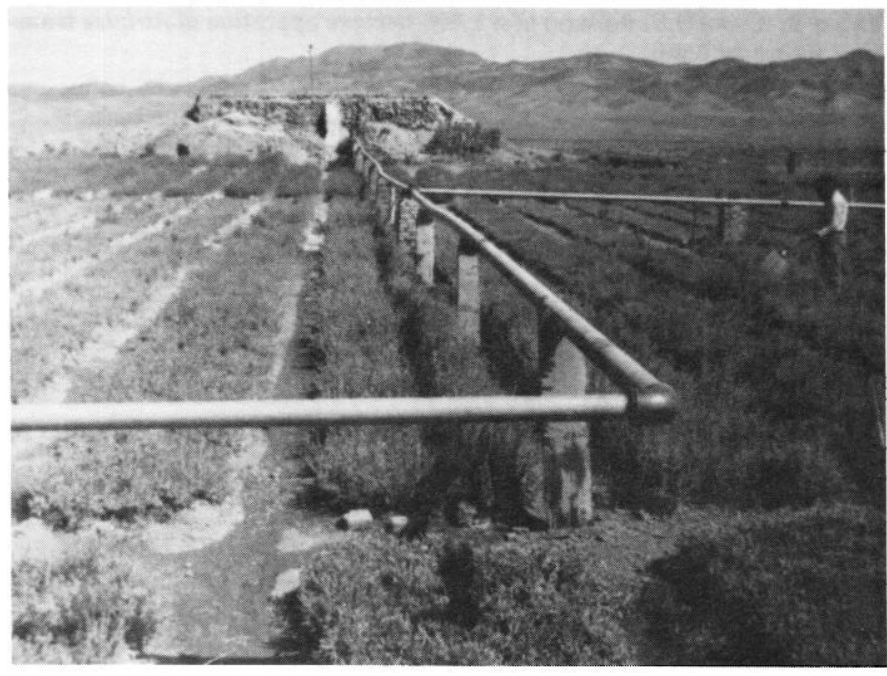

Fig. 1. Atriplex nursery at Zarand-Saveh Station.

\section{Methods and Procedures}

\section{Effect of Time of Transplanting of Bareroot} and Bagged Plants on Plant Survival

Three-month-old seedlings of each of the three species from nurseries (Fig. 1) adjacent to each site were transplanted in prepared contour furrows. Transplanting was done at 15-day intervals from June until December. Planting was by hand labor. Bareroot plants and bagged plants were transplanted. Evaluation of treatment (bagged vs bareroot; season of transplanting) was based on data obtained from 600 single plant observations for each treatment.

To permit roots to extend from plastic bags, 2 to 3 cuts were made on the sides of bags at the time of transplanting.

Contour furrows were spaced at $4 \mathrm{~m}$ and the distance between plants along the contour was $3 \mathrm{~m}$. Seedlings were irrigated at the time of transplanting.

\section{Transplant Height and Survival Study}

During 1972-73 we determined the effect of height of Atriplex canescens transplants on survival. Ten transplants in each of 10 furrows were selected at random and labeled. Height was measured and recorded. Survival data were compared with transplant height classes.

\section{Production Study}

In the fall of 1972 , herbage production of the 1968 plantings at Darizak was determined for Atriplex canescens and for native species (Fig. 2). Square-meter clip plots were located at 10 -m intervals along a randomly located transect. Twig growth of the current year of Atriplex canescens and associated native shrubs and standing crop of grasses

Table 2. Chemical and textural anaysis of soils from Yazdan Range which is a typical soil of the Steppic Zone of Iran.

\begin{tabular}{|c|c|c|c|}
\hline \multirow[b]{2}{*}{ Analysis ${ }^{\mathrm{a}}$} & \multicolumn{3}{|c|}{ Soil sample } \\
\hline & 1 & 2 & 3 \\
\hline $\mathrm{pH}$ & 8.8 & 8.7 & 8.9 \\
\hline $\mathrm{P}_{2} \mathrm{O}_{5}(\mathrm{ppm})$ & 20 & 8 & 10 \\
\hline $\mathrm{Ca}(\mathrm{ppm})$ & 34,500 & 34,400 & 30,000 \\
\hline $\mathrm{Na}(\mathrm{ppm})$ & 445 & 385 & 19,500 \\
\hline $\mathrm{K}(\mathrm{ppm})$ & 45 & 25 & 30 \\
\hline $\begin{array}{l}\text { Soluble salts } \\
\left(\mathrm{EC}_{\mathrm{e}} \times 10^{3}\right)\end{array}$ & .77 & 0.63 & 2.2 \\
\hline Organic matter $(\%)$ & 0.10 & 0.12 & 0.12 \\
\hline Sand $(\%)$ & 73 & 87 & 17 \\
\hline Silt $(\%)$ & 17 & 9 & 27 \\
\hline Clay (\%) & 10 & 4 & 56 \\
\hline
\end{tabular}

\footnotetext{
${ }^{\mathrm{a}}$ Analyses made by the soil laboratory of Alborz Research Center
}

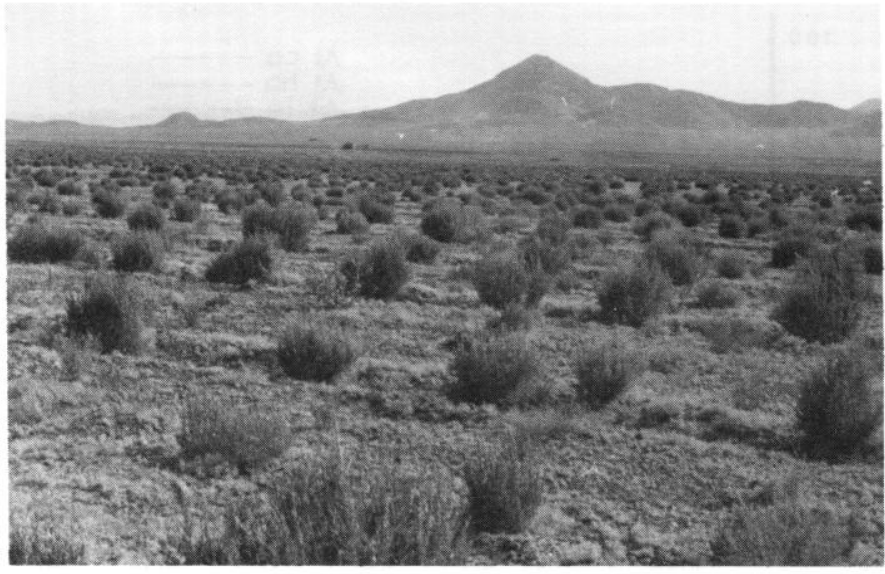

Fig. 2. Karizak Range 4 years after transplanting of Atriplex canescens.

and forbs for each plot were clipped, air dried, and weighed. Data obtained were used to calculate the carrying capacity of treated and untreated range. Statistical confidence intervals $(95 \%)$ were determined for the production data.

\section{Cost of Transplanting}

Cost of transplanting on a per hectare basis was determined for a large scale transplanting operation, including costs of labor, material, and equipment. Equipment cost for contour furrowing was estimated on a rental basis; depreciation costs were charged for owned equipment.

\section{Result and Discussion}

\section{Transplant Survival in Field}

Percent survival as related to different planting dates of bagged and bare root transplants at Zarand-Saveh Range, which is typical at all sites, is shown in Figures 3 and 4 . On a transplant time basis, percent survival of all species at the three sites had the same pattern. Maximum survival varied from site to site between June, July, August, and December transplanting. Maximum survival of Atriplex halimus and Atriplex lentiformis was from September plantings. In general, survival of bagged and bare root Atriplex canescens transplants was higher than the two other species at all three sites. Peak survival of bagged transplants was almost $85 \%$ for Atriplex canescens and for bare root transplants was almost $45 \%$. Maximum survival of bagged Atriplex halimus and Atriplex lentiformis was about $40 \%$ and for bare root was about $25 \%$. Survival of Atriplex halimus and

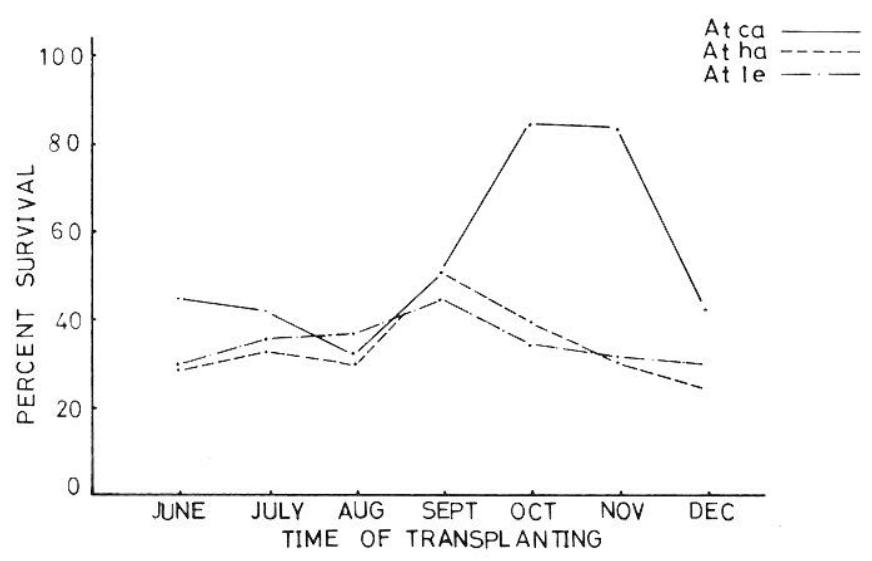

Fig. 3. The average percent survival of plastic bag transplants recorded in 1971 and 1972 from Zarand-Saveh. (Atca $=$ A. canescens, Atha $=\mathrm{A}$. halimus, Atle $=$ A. lentiformis.) 


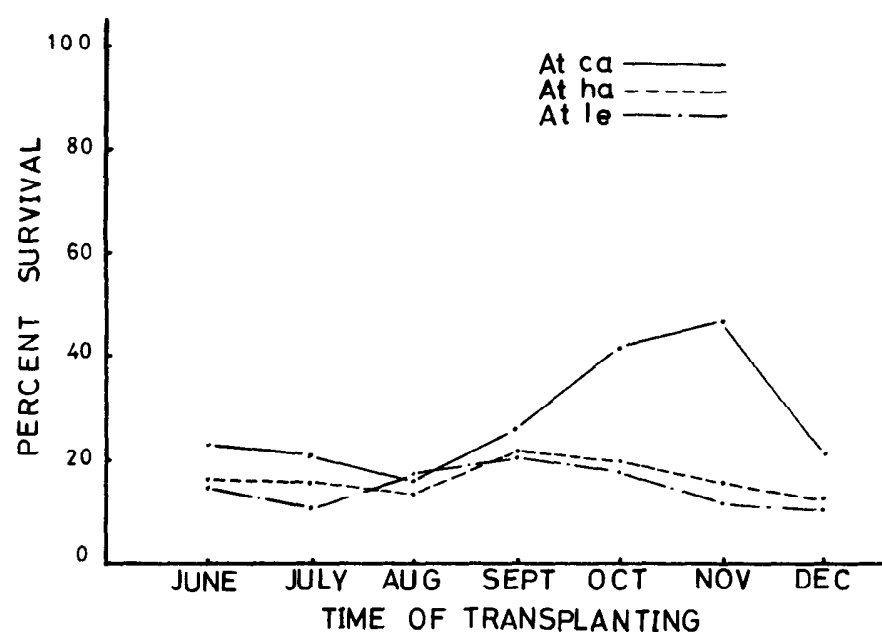

Fig. 4. The average percent survival of bare root transplants, recorded in 1971 and 1972 from Zarand-Saveh. $($ Atca $=$ A. canescens, Atha $=$ A. halimus, Atle $=$ A. lentiformis.)

Atriplex lentiformis varied only slightly through time at the three sites. An increase in survival of bagged transplants began with August transplanting and continued to get better until the best survival rates were obtained from September for Atriplex halimus and Atriplex lentiformis and from October and November for Atriplex canescens transplanting, after which survival again declined.

\section{Transplant Height and Survival}

There was a relationship between height of transplants and percent survival (Fig. 5). Percent survival was low when transplants were $5 \mathrm{~cm}$ high. With an increase in height, percent survival increased. The best survival was obtained from transplants of 20 to $30 \mathrm{~cm}$ height at time of transplanting.

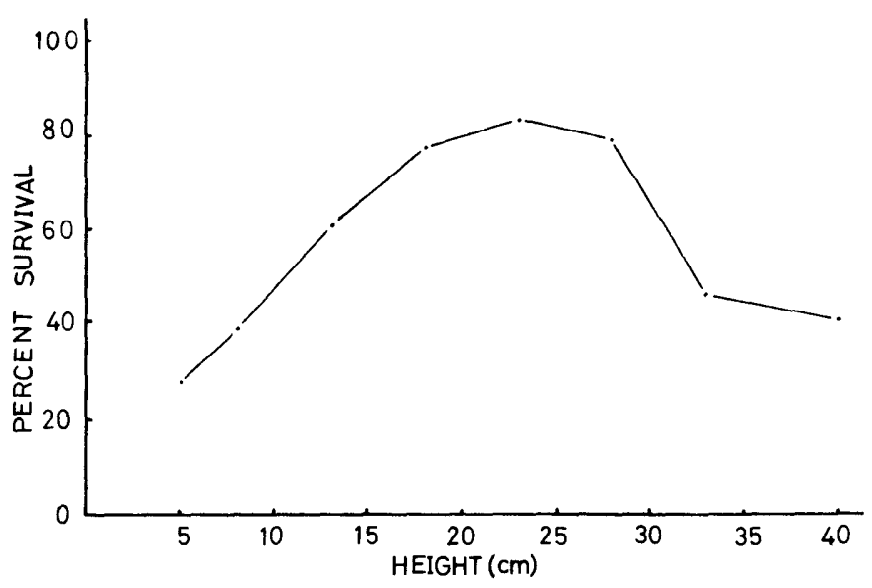

Fig. 5. The relationship between height of Atriplex canescens transplants and percent survival at Zarand-Saveh.

\section{Production}

Mean production $(\mathrm{kg} / \mathrm{ha})$ for the treated and untreated area was $508 \mathrm{~kg}$ and $150 \mathrm{~kg}$. Statistical confidence intervals for the transplanted area were from 335 to $680 \mathrm{~kg}$ and for the nontransplanted area were from 125 to $179 \mathrm{~kg}$. Even though there was considerable variation in production within the transplanted area, the difference in production between treated and nontreated areas was highly significant.
Table 3. Cost (U.S. dollars) of a 1,000-hectare operation of Atriplex transplanting in Iran.

\begin{tabular}{lccc}
\hline \hline Item & Amount & Cost/unit & $\begin{array}{r}\text { Total cost } \\
(1,000 \mathrm{ha})\end{array}$ \\
\hline Plastic bags & $4,500 \mathrm{~kg}$ & $\$ 1.00 / \mathrm{kg}$ & $\$ 4,500.00$ \\
Manure & $250 \mathrm{~m}^{3}$ & $5.71 / \mathrm{m}^{3}$ & $1,427.50$ \\
$\begin{array}{l}\text { Sand } \\
\text { Contour furrowing }\end{array}$ & $800 \mathrm{~m}^{3}$ & $3.57 / \mathrm{m}^{3}$ & $2,856.00$ \\
$\quad \begin{array}{l}\text { and diking } \\
\text { Raising and } \\
\text { transplanting }\end{array}$ & $1,000 \mathrm{ha}$ & $2.31 / \mathrm{ha}$ & $2,310.00$ \\
$\begin{array}{l}\text { Depreciation of equip- } \\
\text { ment (3 tractors, }\end{array}$ & $1,000,000$ & & $58,500.00$ \\
5 water-tanks, 3 disk & seedlings & - & \\
plows, and 2 trailers) & - & & \\
Total & & & $3,142.86$ \\
Cost/ha & & & $72,736.36$ \\
\hline
\end{tabular}

Because production of native and transplanted species was combined to obtain total production, the increased yields from the treated area can be attributed to yield from the introduced shrubs plus the increased production at native species.

Increase in production of native species was due to changes in the microclimate. Change in microclimate can be expected from: (1) protection, (2) irrigation of transplants at time of the transplanting, and (3) wind effect decreased for understory vegetation as height of transplants increased.

\section{Cost}

Total cost of a 1,000-hectare operation of transplanting is shown in Table 3 . The total cost of 1,000 hectare was estimated at $\$ 72,736$, which resulted in a cost of $\$ 72.74 / \mathrm{ha}$. These figures apply to operation in the Central Ostan only. In general, the cost will be lower in most other provinces.

\section{Conclusions}

The conclusions were as follows:

1. In the Central Plateau of Iran, the best time to transplant Atriplex halimus and Atriplex lentiformis is September; October and November are best for Atriplex canescens.

2. The best survival will be with transplants 20 to $30 \mathrm{~cm}$ in height.

3. Plastic bag transplanting is more successful than bare root transplanting.

4. Atriplex canescens, as compared to Atriplex halimus and Atriplex lentiformis, is the best adapted shrub species to be transplanted in the Central Plateau of Iran.

5. The total production per hectare can be tripled (from $150 \mathrm{~kg}$ to $400 \mathrm{~kg}$ ) within a maximum 4 -year period by transplanting Atriplex.

6. The cost of transplanting Atriplex was estimated as $\$ 72.74 / \mathrm{ha}$ on a large scale basis. The costs are relatively high in comparison with other range rehabilitation practices, but the chances of success also are higher.

\section{Literature Cited}

Aldon, E. F. 1972. Critical soil moisture levels for field planting fourwing saltbush. J. Range Manage. 25:311-312.

Plummer, A. P., S. B. Monsen, and D. R. Christensen. 1966. Fourwing saltbush-a shrub for future game range. Utah State Dep. Fish and Game Pub. No. 66-4.

Springfield, H. W. 1972. Using mulches to establish woody chenopods. U.S. Dep. Agr., Forest Serv. Gen. Tech. Rep. INT-1. 